\title{
SEROTONERGIC METAMODULATION OF MGLU2/3 RECEPTORS, A NEW MECHANISM FOR PAIN MANAGEMENT: THE CASE OF TRAZODONE
}

\author{
B. Garrone ${ }^{1}$, G. Olivero² , C. Milanese ${ }^{1}$, A. Roggeri², G. Vallarino², \\ F. P. Di Giorgio1, A. Pittaluga ${ }^{2,3}$
}

${ }^{1}$ Angelini Pharma S.p.A., Rome, Italy

2 Department of Pharmacy, DiFAR, Pharmacology and Toxicology Section, University of Genoa, Genoa, Italy

${ }_{3}$ IRCCS Ospedale Policlinico San Martino, Genoa, Italy

E-mail: olivero@difar.unige.it

Doi: 10.36118/pharmadvances.2021.19

\begin{abstract}
SUMMARY
Trazodone (TZD) is commonly used for depression and insomnia and the likely effect accounting for its antidepressant activity is its antagonistic action at serotonergic receptors, particularly the $5-\mathrm{HT}_{2 \mathrm{~A}}$ receptors. However, emerging evidence supports the application of TZD for the management of chronic pain. Several cellular events are potentially involved in its antalgic activity, and, among them, there is the metamodulation linking $5-\mathrm{HT}_{2 \mathrm{~A}}$ and $\mathrm{mGlu} 2 / 3$ receptors in spinal cord glutamatergic nerve endings. The term "metamodulation" refers to the integration of the neuronal signal involving colocalized receptors functionally and even physically associated. These receptors can influence each other, finely tuning the efficiency of synaptic transmission.

The aim of this review is to analyze the data from both in vitro and in vivo preclinical studies proving the existence and the functional interaction linking $5-\mathrm{HT}_{2 \mathrm{~A}}$ and $\mathrm{mGlu2/3}$ receptors. The review then focuses on the maladaptation of this metamodulatory interaction in the spinal cord of animals suffering from sciatic ligation and finally describes the impact of TZD on the $5-\mathrm{HT}_{2 \mathrm{~A}}-\mathrm{mGlu2/3}$ metamodulation in both physiological and pathological conditions.

In this context, new unpublished results from in vivo preclinical studies in a chronic constriction injury rat model of neuropathic pain are provided which confirm the analgesic effect of TZD on mechanical hyperalgesia and spontaneous pain in these rats.

In conclusion, in a whole the data unveil a cellular mechanism that could subserve the analgesic activity of TZD and support its use in clinic for pain management.
\end{abstract}

\section{Key words}

Neuropathic pain; 5-HT 2 receptor; $m$ Glu2/3 receptor; metamodulation; trazodone.

\section{INTRODUCTION}

Since its introduction in therapy in the early 1970s, trazodone (TZD) hydrochloride has been used for the treatment of depression

\section{Impact statement}

The $5-\mathrm{HT}_{2 \mathrm{~A}}$ antagonist trazodone is a potent metamodulator of the spinal $\mathrm{mGlu2/3}$ autoreceptors and recovers their efficiency in controlling glutamate exocytosis, supporting its use for the management of pain.

and often administered in association with other antidepressants to patients with insomnia. The drug is well tolerated, with a favorable pharmacokinetic profile and convenient 
pharmacodynamic characteristics (1-6). It is commonly referred to as a serotonin $(5-\mathrm{HT})$ receptor antagonist and serotonin reuptake inhibitor (SARI) (7), although its potency to block the 5-HT reuptake is lower than that of other specific serotonin reuptake inhibitors (SSRIs), such as citalopram and fluoxetine (8). The most likely effect accounting for its antidepressant activity is the antagonistic action at serotonergic receptors, particularly the $5-\mathrm{HT}_{2 \mathrm{~A}}$ and the $5-\mathrm{HT}_{2 \mathrm{C}}$ receptors $(1,6,9)$. The simultaneous inhibition of serotonin transporters (SERTs) and of the $5-\mathrm{HT}_{2 \mathrm{~A}} / 5-\mathrm{HT}_{2 \mathrm{C}}$ receptors leads to a synergistic action which potentiates the antidepressant activity and improves the tolerability, reducing some of the side effects exerted by classic antidepressants, including insomnia and anxiety $(2,6)$. TZD also antagonizes the $5-\mathrm{HT}_{2 \mathrm{~B}}$ receptors, although less efficiently than the $5-\mathrm{HT}_{2 \mathrm{~A}}$ ones and has a partial agonistic activity towards the $5-\mathrm{HT}_{1 \mathrm{~A}}$ receptors (1). Furthermore, it interacts with noradrenergic $\alpha_{1}$ receptors, but has minimal antagonistic activity on cholinergic and histaminergic $\mathrm{H}_{1}$ receptors (6). Despite the use in practice of TZD preferentially relates to the cure of major depressive disorder, evidence is emerging supporting its application for the management of other pathological conditions, including chronic pain (10). The present review reports recent literature and unpublished data concerning the role of TZD as a "metamodulator" of the mGlu2/3 autoreceptors, which would support its application for the treatment of neuropathic pain.

\section{5-HT ${ }_{2 A}$ RECEPTORS IN THE CENTRAL NERVOUS SYSTEM}

The 5- $\mathrm{HT}_{2 \mathrm{~A}}$ receptors, which represent a preferential target of TZD (11), are G protein-coupled receptors (GPCRs) which bind Gq/Gi proteins to control phospholipase C (PLC)-protein kinase $C$ (PKC)-dependent intraterminal pathway(s), that ultimately mobilize(s) calcium ions from the endoplasmic reticulum, then promoting cell functions. $5-\mathrm{HT}_{2 \mathrm{~A}}$ receptors have a widespread distribution in the central nervous system (CNS), where they locate both presynaptically and postsynaptically to control the strength of synaptic connections, particularly at excitatory synapses (12-15). In 1997, Aghajanian and Marek provided evidence describing the existence of $5-\mathrm{HT}_{2 \mathrm{~A}}$ receptors having a preferential postsynaptic distribution, whose activation significantly increases the frequencies and the amplitude of the postsynaptic excitatory spontaneous currents at pyramidal cells of the $V$ cortical layer (13). Postsynaptic $5-\mathrm{HT}_{2 \mathrm{~A}}$ receptors were also proposed to exist in GABAergic neurons in the spinal cord (14, $16,17)$ and to exert at this level an indirect tonic inhibition of glutamatergic innervation useful for analgesic activity (as discussed below, see paragraph $7(14,18)$ ).

A decade later, functional evidence also unveiled the presynaptic distribution of the $5-\mathrm{HT}_{2 \mathrm{~A}}$ receptors in cerebellar (19), cortical (12) and spinal cord glutamatergic terminals (15). These presynaptic release-regulating $5-\mathrm{HT}_{2 \mathrm{~A}}$ heteroreceptors shared a common pharmacological profile and were typified by a huge affinity for TZD that behaved in all regions as a receptor antagonist. Differently from the $5-\mathrm{HT}_{2 \mathrm{~A}}$ receptors located postsynaptically, the presynaptic $5-\mathrm{HT}_{2 \mathrm{~A}}$ receptors preferentially inhibited, instead of potentiating, glutamate exocytosis. A negative control of PLC/PKC intraterminal pathways reducing in this case the gating of Voltage-Operated Calcium Channels in plasma membranes was proposed to subserve the $5-\mathrm{HT}_{2 \mathrm{~A}}$ receptor-mediated inhibitory effect (12).

\section{5-HT ${ }_{2 \mathrm{~A}}$-MGLU ${ }_{2 / 3}$ METAMODULATION IN THE CENTRAL NERVOUS SYSTEM}

The term "metamodulation" refers to a particular mechanism of integration of the neuronal signal which dramatically enhances the complexity of the synaptic network. It involves colocalized receptors functionally and even physically associated in plasma membranes that, beside their ability to control directly the neuronal activity, participate to an intramembrane integrated interaction which assures a recep- 
tor-receptor cross-talk whereby a neuromodulator acting at one receptor indirectly affects the activity of a second neuromodulator acting at the colocalized receptor (20-22).

Central $5-\mathrm{HT}_{2 \mathrm{~A}}$ receptors recently emerged to the interest of pharmacologists for their ability to couple the group II metabotropic glutamate receptors subtype 2 and 3 (mGlu2/3; (23-30); figure 1). This functional cross-talk was proposed on the basis of in vivo observations (3136) and then definitively proven by in vitro results confirming their physical and functional association in the cortex of mammals (24-30, $32,37-41)$. The mGlu2/3 receptors, particularly the $\mathrm{mGlu} 2$ receptor proteins, were reported to physically connect the $5-\mathrm{HT}_{2 \mathrm{~A}}$ receptor proteins by means of specific aminoacid(s) within the intraterminal $\mathrm{COOH}$ tail (41). This structural interaction is allosteric in nature, but, differently from most of the receptor-receptor cross-talk described in the literature (A2-D2 receptors $(42,43)$; sst5-NMDA receptors $(22,44)$; nicotine and NMDA receptors (45-51)) is an antagonist-like cross-talk, since the activation of the mGlu2/3 receptors reduces the functional responses elicited by the colocalized $5-\mathrm{HT}_{2 \mathrm{~A}}$ receptors $(25,28,40)$.
As far as the cortex is concerned, the $5-\mathrm{HT}_{2 \mathrm{~A}}$-mGlu2/3 receptor-receptor cross-talk was preferentially investigated unidirectionally, by analyzing the impact of the $\mathrm{mGlu} 2 / 3$ ligands on the $5-\mathrm{HT}_{2 \mathrm{~A}}$ receptor-evoked responses (36, 52-55), giving scarce attention to the reciprocal relationship, i.e. whether and how $5-\mathrm{HT}_{2 \mathrm{~A}}$ receptors ligands influence the $\mathrm{mGlu} 2 / 3$ receptor-mediated signals $(25,30,41)$.

The $\mathrm{mGlu2} / 3$ receptors have a wide-spread distribution in the CNS, and exist presynaptically on glutamatergic nerve endings, in different regions of the mammal CNS, including the spinal cord, where they inhibit glutamate release $(15,21,56-59)$. Spinal cord glutamatergic nerve endings also possess inhibitory presynaptic $5-\mathrm{HT}_{2 \mathrm{~A}}$ heteroreceptors, whose activation efficiently hampers glutamate release as well (15). Biochemical and functional studies unveiled that also in spinal cord glutamatergic isolated nerve endings (we refer to as synaptosomes) the mGlu2/3 and the $5-\mathrm{HT}_{2 \mathrm{~A}}$ receptors colocalize and functionally couple to control glutamate exocytosis (figure 2).

The colocalization of the two receptors emerged in confocal microscopy analysis, which showed the presence of both receptors

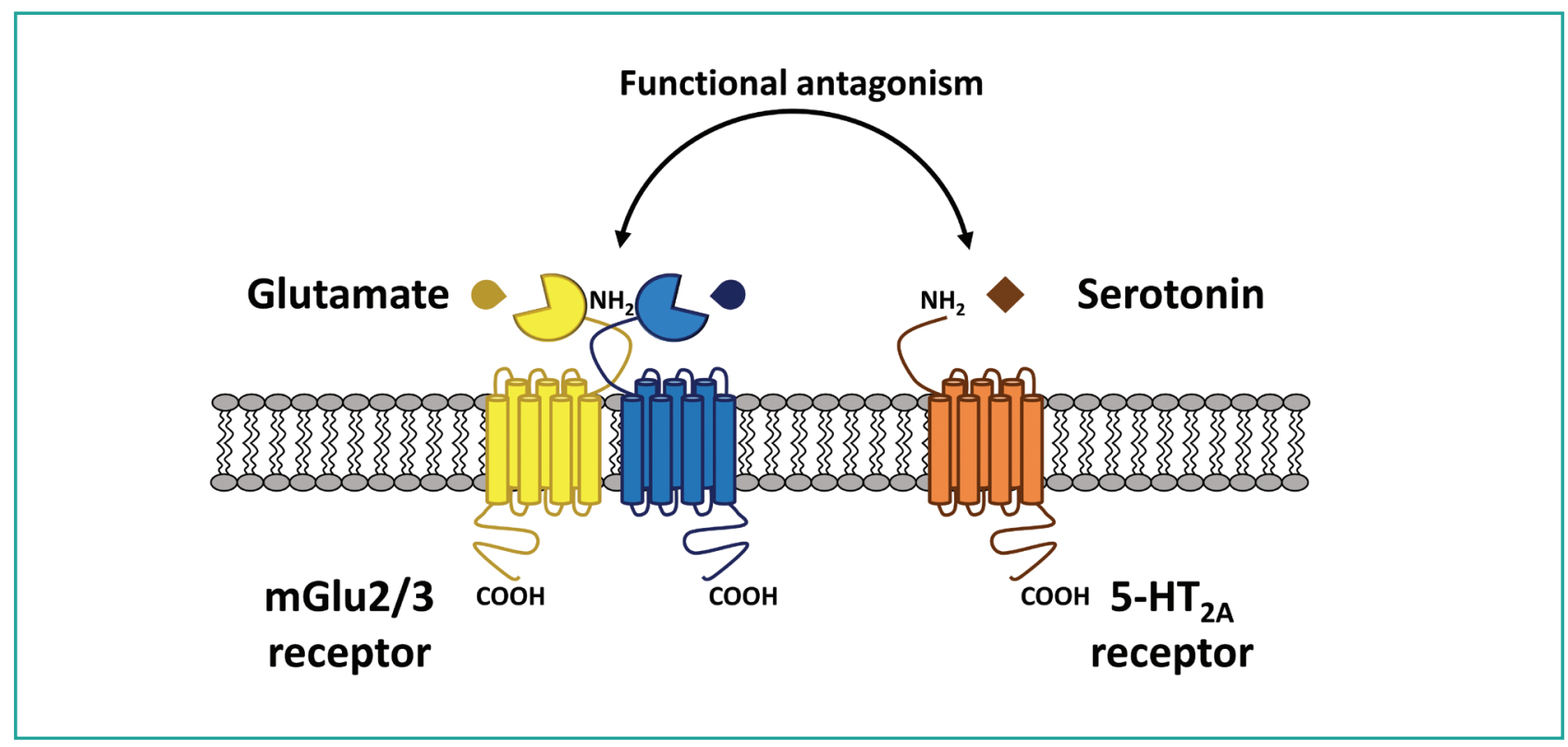

Figure 1. Glutamatergic mGlu2/3 receptors and serotonergic $5-\mathrm{HT}_{2 \mathrm{~A}}$ receptors colocalize and associate in a heterodimeric assembly, metamodulating in an antagonist manner their functions. 


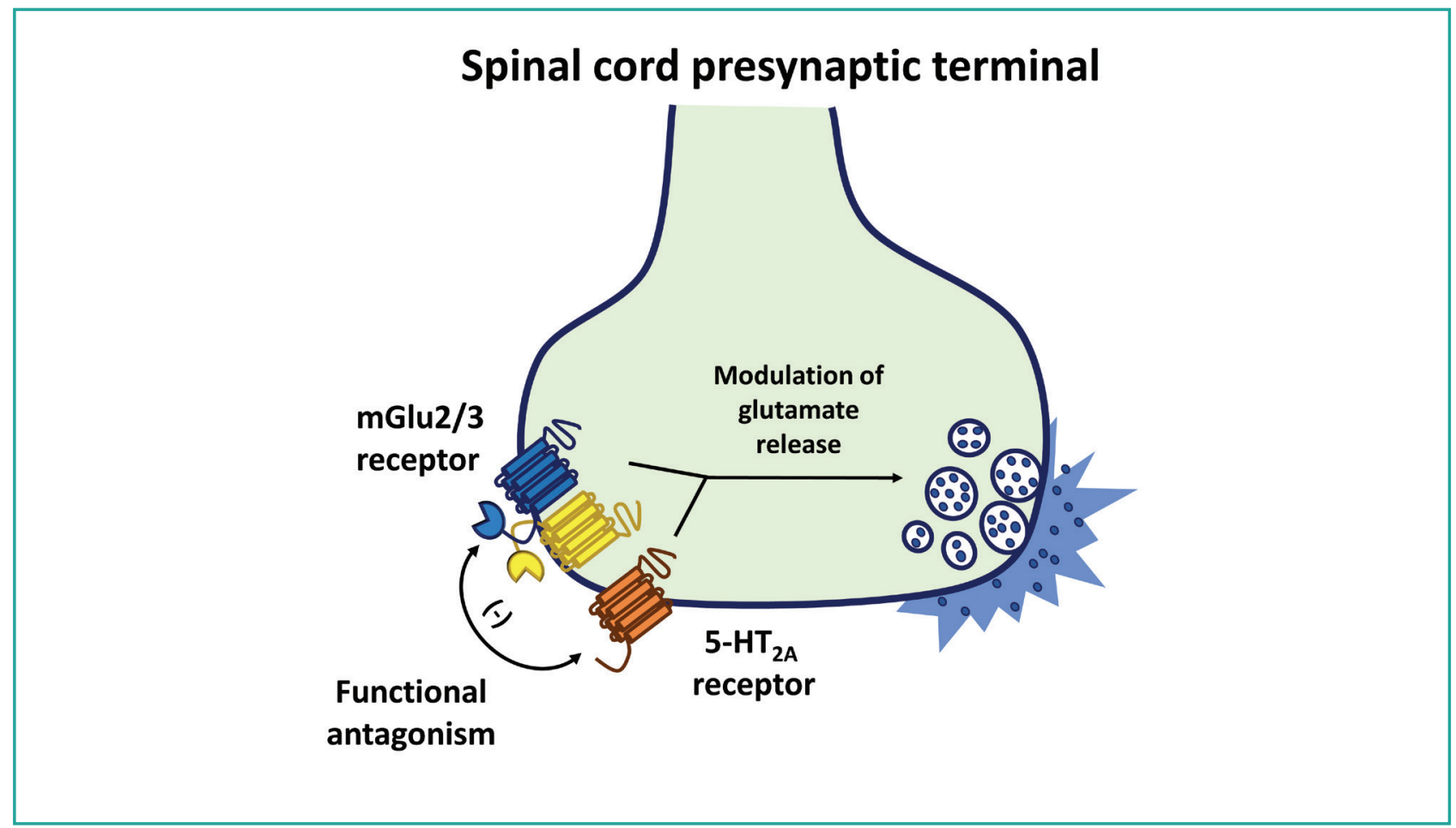

Figure 2. The glutamatergic nerve endings isolated from the spinal cord of adult rats are endowed with both $5-\mathrm{HT}_{2 \mathrm{~A}}$ and $\mathrm{mGlu2/3}$ receptors that assembly in a receptor-receptor heterocomplex to metamodulate glutamate exocytosis.

in spinal cord glutamatergic synaptosomes. Then, immunoprecipitation studies demonstrated that the mGlu2/3 receptor protein immuno-precipitates from synaptosomal lysates were also immunopositive for the $5-\mathrm{HT}_{2 \mathrm{~A}}$ receptor protein, consistent with the physical association of the two receptor proteins in nerve endings (15). Finally, functional studies carried out with the "up-down superfusion technique" (60-62) demonstrated that, beside controlling directly glutamate exocytosis, the two receptors were functionally coupled to dynamically metamodulate their releasing activity at glutamatergic terminals (15).

Differently from the cortex, the study of mGlu2/3-5- $\mathrm{HT}_{2 \mathrm{~A}}$ receptor-receptor metamodulation in spinal cord glutamatergic nerve endings preferentially focused on the serotonergic tuning of the mGlu2/3 autoreceptors. It emerged that 5- $\mathrm{HT}_{2 \mathrm{~A}}$ antagonists, including TZD, behaved as an "indirect positive allosteric modulator" (IPAMs) of the presynaptic release-regulating $\mathrm{mGlu2/3}$ autoreceptors, since blockade of the $5-\mathrm{HT}_{2 \mathrm{~A}}$ receptors reinforced the mGlu2/3-mediated presynaptic inhibition of glutamate release and, conversely, activation of the $5-\mathrm{HT}_{2 \mathrm{~A}}$ receptor nulled the mGlu2/3-mediated control of glutamate exocytosis (15). In particular, low (1-3 pM) concentrations of the mGlu2/3 receptors agonist LY379268, unable to inhibit on their own the glutamate exocytosis, became active in synaptosomes that were concomitantly exposed to TZD or other $5-\mathrm{HT}_{2 \mathrm{~A}}$ antagonists. An increased insertion of the $\mathrm{mGlu} 2 / 3$ receptor proteins into the synaptosomal membranes subserved the TZD-mediated reinforcement of the mGlu2/3 receptors-mediated effect, unveiling a quick (within minutes) trafficking of the $\mathrm{mGlu2/3}$ receptor proteins from a cytosolic compartment to the synaptic membranes. This event is efficiently "metamodulated" by the colocalized $5-\mathrm{HT}_{2 \mathrm{~A}}$ receptors that by dictating the membrane distribution of the glutamatergic autoreceptors tunes their desensitization state (figure 3 ) (15). 


\section{Spinal cord presynaptic terminal}

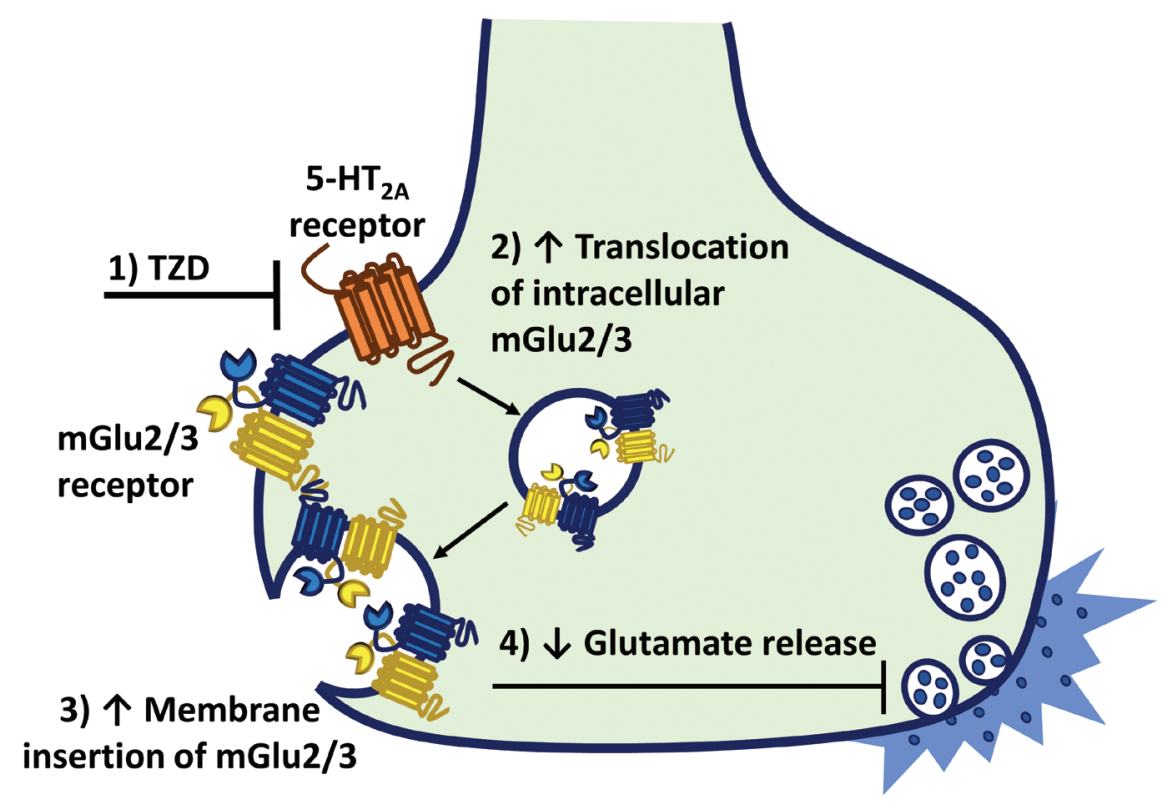

Figure 3. Trazodone antagonizes the presynaptic 5- $\mathrm{HT}_{2 \mathrm{~A}}$ heteroreceptors in spinal cord glutamatergic nerve endings, favoring the insertion of $\mathrm{mGlu2/3}$ receptor proteins in plasma membranes and reinforcing the inhibitory feed-back mechanism of auto-control of glutamate exocytosis. This would limit glutamate exocytosis interfering with the mechanisms of sensitization that support hyperalgesia and allodynia.

\section{5-HT 2 -MGLU2/3 METAMODULATION IN THE CENTRAL NERVOUS SYSTEM: FROM PHYSIOLOGY TO PATHOLOGY}

The metamodulation unveils a huge, unexpected complexity of the central neuronal communication, that increases even more when shifting from physiological to pathological conditions. In general, a receptor-receptor interaction is first analyzed in physiological conditions, to deepen the knowledge of the mechanisms by which one receptor influences the colocalized one $(47,51,62,63)$. Afterwards, the study often turns to pathological conditions, to investigate whether and how the receptor-receptor cross-talk is modified during the course of disease or, conversely, if conditions impairing the metamodulation subserve the onset of a central disorder. In this case, the study can be further extended to verify whether receptor ligands can recover the metamodulation to physiological levels, paving the road for the use of these drugs for new therapeutic purposes $(21,45,50,51)$.

As far as the pathogenetic role of the $\mathrm{mGlu2/3-}$ $5-\mathrm{HT}_{2 \mathrm{~A}}$ receptor-receptor interaction in the cortex is concerned, changes in the $\mathrm{mGlu2/3}$ receptors-mediated control of the $5-\mathrm{HT}_{2 \mathrm{~A}}$ receptors were associated to the development of psychosis, as well as to altered responsiveness of schizophrenic patients to antipsychotics (25, $36,52,53,64)$. These observations led to hypothesize that modulators of the mGlu2/3-5$\mathrm{HT}_{2 \mathrm{~A}}$ receptors interaction could provide new therapeutic approaches for the management of schizophrenia $(40,55,65,66)$. According to the hypothesis, $\mathrm{mGlu2/3}$ receptor agonists, or even better mGlu2/3 positive allosteric modulators (PAMs), were analyzed for the cure of psychiatric illness and still represent promising approaches, as recently reviewed by Ferdinando Nicoletti and colleagues (67), despite the heterogeneity of the results from preclinical 
studies and the negative results of some of the clinical studies carried out so far (reviewed by (68), but see also (69)).

Recently, we proposed that the mGlu2/3-5$\mathrm{HT}_{2 \mathrm{~A}}$ receptors functional crosstalk could also have a pathogenic role in spinal pathologies, particularly in nociception (70). The hypothesis originated from the observations of functional adaptations of both the $\mathrm{mGlu2} / 3$ and the $5-\mathrm{HT}_{2 \mathrm{~A}}$ receptors in spinal cord glutamatergic nerve endings isolated from animal suffering from sciatic nerve ligation. In these animals it emerged that i) the efficiency of glutamate exocytosis is impaired, being significantly increased when compared to healthy animals, ii) the expression of presynaptic release-regulating mGlu2/3 autoreceptors is significantly reduced at the acute stage of disease, while that of the $5-\mathrm{HT}_{2 \mathrm{~A}}$ receptors is largely conserved and, last but not least, iii) the presynaptic releasing-regulating activities of both the mGlu2/3 and the $5-\mathrm{HT}_{2 \mathrm{~A}}$ receptors are modified, the two receptors undergoing opposite functional adaptations (as described in paragraphs 5 and 6, see (70)). Before describing the results supporting our hypothesis, the role of glutamate and serotonin (and of the mGlu2/3 and the $5-\mathrm{HT}_{2 \mathrm{~A}}$ receptors) in nociception and analgesia will be briefly resumed.

\section{GLUTAMATE AND MGLU2/3 RECEPTORS IN NEUROPATHIC PAIN}

Hyperalgesia and allodynia elicited by acute nerve injury, inflammation or thermal/mechanical overstimulation rely on a cascade of events that mainly involves the spinal glutamatergic innervation. A continuous self-amplifying raise of extracellular glutamate occurs in the spinal cord of animal suffering from neuropathic pain (71-73) that is sustained by concomitant maladaptive adaptations including: i) impaired glutamate uptake efficiency, ii) increased efficiency of glutamate exocytosis from nerve terminals (and possibly astrocytes); ii) loss of function of receptors, particularly of the $\mathrm{mGlu} 2 / 3$ autoreceptors, which affects glutamate release and ultimately favours the central neuronal sensitization.

The excitatory amino acid transporters type 1 and 2 (EAAT1 and EAAT2), which mainly account for the uptake of glutamate in astrocytes (EAAT1, GLAST) and nerve terminals (EAAT2, GLT1) (74), control pain perception, as suggested by the finding that the intrathecal administration of EAAT inhibitors causes nociceptive behaviour in animals (75). In particular, the reduced expression of EAATs in the spinal cord of injured animals is an early mark of neuropathic pain $(76,77)$, which becomes evident soon after ( 7 days) the peripheral nerve injury $(12,78-80)$, but rapidly recovers during pain sensitization (75). A concomitant amplification of glutamate exocytosis $(70,81)$ parallels the EAAT1/2 malfunctioning and contributes to the altered glutamate homeostasis in the injured animals $(73,82)$. The scenario is even more worsened by the desensitization of the presynaptic inhibitory mGlu2/3 autoreceptors, which definitively supports the hyper-glutamatergicity $(70,83-84)$. The loss of functions of the mGlu2/3 autoreceptor strictly depends on the gravity and the timing of the injury, being detectable shortly after the lesion (at the seventh day after the injury), but largely recovering at the chronic stage of sensitization (about at the twentieth day after the injury, see $(70,84-85)$. The dynamic adaptability of the mGlu2/3 receptors suggested these proteins as suitable targets for therapeutic treatments to manage nociception (86-89) and the pharmacological approaches so far proposed include: the administration of orthosteric and allosteric agonists which directly potentiate the mGlu2/3 receptor-mediated signaling (reviewed by (89)) and of enzyme inhibitors that indirectly modulate the receptors by controlling the production of endogenous agonists (i.e., the inhibitors of the glutamate carboxypeptidases II and III, which control the availability of $\mathrm{N}$-acetyl-aspartyl-glutamate, the endogenous mGlu3 agonist, (90).

The administration of modulators of the glutamate transporters to indirectly force the acti- 
vation of the mGlu2/3 autoreceptors. It is the case of $\mathrm{N}$-acetyl cysteine (NAc), which dictates the bioavailability of endogenous glutamate by tuning the glial glutamate-cystine membrane exchanger. NAc reduces the transmission of responses to nociceptive reflexes in rodents and humans through a mechanism involving the mGlu2/3 receptors $(91,92)$.

The epigenetic control of the mGlu2 receptor expression with acetyl donors (i.e., L-acetylcarnitine, already marketed for the management of neuropathic pain) or histone deacetylase inhibitors (87).

Their use is limited by the onset of side-effects, i.e., the tolerance after repeated administration (in the case of the drugs for the former approach $(89,91,92)$ or the lack of region-specificity leading to unwanted harmful reactions (for drugs belonging to the second and the third groups).

\section{SEROTONIN AND 5-HT 2 RECEPTORS IN NEUROPATHIC PAIN}

The main role of $5-\mathrm{HT}$ in controlling nociception was definitively highlighted by using the Lmx1b conditional knock-out mice ( $\mathrm{Lm} \times 1 \mathrm{~b}$ $f / f / p)$, which lack central serotonergic neurons and show enhanced inflammatory pain, that largely recovers following the intracerebroventricular injection of 5-HT (93). The analgesic effect of 5-HT is also observed in injured animals administered the neurotransmitter precursor 5-hydroxytryptophan, which reduces nociception (revised by (94)). The analgesic activity of the neurotransmitter was proposed to reside on its pro-regenerative activity, which would favour locally the synaptic plasticity and the regrowth of axons (as discussed by (94)), also exerting anti-inflammatory properties which reduce pain sensitization (93).

The therapeutic activity of 5-HT involves the 5-HT receptors, that represent therefore specific targets for the therapeutic management of neuropathic pain (see for an exhaustive review (95)). In particular, the role of $5-\mathrm{HT}_{2 \mathrm{~A}}$ receptors in controlling spinal algia was high- lighted in 2007 by Okamoto and colleagues (96) and ten years later by Lopez-Alvarez and colleagues (97). These authors reported an altered expression of the $5-\mathrm{HT}_{2 \mathrm{~A}}$ receptors in the spinal cord dorsal horn following sciatic nerve transection in rats during the first 2 weeks after injury. Other authors $(98,99)$ provided evidence showing that the $5-\mathrm{HT}_{2 \mathrm{~A}}$ subtype receptors are upregulated and tonically active in the dorsal horn of animals suffering from the spinal nerve ligation. Furthermore, an efficient reduction of pain perception and analgesia was observed following both systemic and local administration of $5-\mathrm{HT}_{2 \mathrm{~A}}$ receptor antagonists, (including ketanserin or M100907, revised by (95)), well consistent with the efficacy of these drugs to reduce the feed-back mechanisms of auto-control of 5-HT release in nerve endings.

To investigate the molecular mechanism(s) accounting for the analgesic properties of the $5-\mathrm{HT}_{2 \mathrm{~A}}$ antagonists, Pichon and colleagues in 2010 focussed on the postsynaptic $5-\mathrm{HT}_{2 \mathrm{~A}}$ receptors located on spinal GABAergic interneurons (14). The authors demonstrated that the expression of these receptors is not modified in the spinal cord of diabetic rats suffering from neuropathic pain, but rather that they functionally desensitize, losing their analgesic properties. The mechanism accounting for the receptor desensitization was proposed to involve the postsynaptic density protein-95 (PSD-95), which is a marker of the postsynaptic component of synapsis, that is upregulated in the spinal cord of diabetic rats suffering from neuropathic pain. PSD95 contains PDZ motifs that permit the physical and functional interaction with colocalized proteins, including selected intraterminal sequences of the $5-\mathrm{HT}_{2 \mathrm{~A}}$ receptors. By using a peptide that disrupt the interaction between the PDZ motif of PSD95 and the $5-\mathrm{HT}_{2 \mathrm{~A}}$ receptor $\mathrm{C}$-terminus, the authors demonstrated that PSD95 silences the serotonergic counterpart, then impeding its activity as modulator of GABA innervation indirectly affecting pain perception $(14,17,18)$. 
More recently, we focussed on the $5-\mathrm{HT}_{2 \mathrm{~A}}$ receptors located presynaptically in spinal cord glutamatergic nerve endings and found that also their expression is largely conserved in injured animals (70). Differently from the postsynaptic ones, however, these receptors did not desensitize but rather became more active in inhibiting glutamate exocytosis (as a matter of fact, concentration of $5-\mathrm{HT}_{2 \mathrm{~A}}$ agonist onefold lower than that activating the receptors in physiological condition was required to significantly reduce the glutamate exocytosis in injured rats), while the colocalized mGlu2/3 autoreceptors lost their inhibitory activity and their density decreased. In a whole, it emerged that the pathological conditions associated to neuropathic pain impair the presynaptic $5-\mathrm{HT}_{2 \mathrm{~A}}-\mathrm{mGlu} 2 / 3$ metamodulation in these terminals, the serotonergic tuning prevailing on the glutamatergic one. Because of the dynamic nature of the metamodulation, we hypothesized that the in vivo administration of $5-\mathrm{HT}_{2 \mathrm{~A}}$ antagonists, i.e., TZD, would reprogram the $5-\mathrm{HT}_{2 \mathrm{~A}}-\mathrm{mGlu} 2 / 3$ cross-talk, re-equilibrating it to physiological levels. The hypothesis was verified in in vivo and in ex-vivo, in vitro studies and the results (which are discussed below on paragraph 7) provided the rationale to the use of TZD for analgesic purposes in individuals suffering from neuropathic pain.

\section{TRAZODONE FOR THE CURE OF NEUROPATHIC PAIN: PRECLINICAL AND CLINICAL EVIDENCE}

The data in the literature concerning the analgesic activity of TZD have been recently reviewed by Belinskaja and colleagues in 2019 (100). The results from in vivo preclinical studies indicated that TZD reduced the responsiveness of mice in the hot plate test (101), decreased the number of writhes in the mice writhing test (102) and slowed the responsiveness in the formalin test in mice (103). Inasmuch, TZD tested in the chronic constriction injury $(\mathrm{CCl})$ rat model of neuropathic pain $(104,105)$ showed a significant anti-hyperal- gesic effect (106). Furthermore, TZD was proven to exert a significant and dose-dependent (0.3-3 $\mathrm{mg} / \mathrm{kg})$ analgesic effect on mechanical hyperalgesia and spontaneous pain in $\mathrm{CCl}$ rats (102).

More recently, Dr. Garrone and co-workers also investigated the impact of TZD on pain threshold and weight bearing deficits in rats suffering from sciatic nerve ligation. In these set of experiments the chronic constriction injury, the evaluation of mechanical hyperalgesia and weight bearing, and the in vivo pharmacological treatments were performed according to (102). These experiments were carried out in accordance with the European Communities Council Directive guidelines (Directive 2010/63/EU of September 22, 2010) and approved by the National Council on Animal Care of the Italian Ministry of Health (Authorization n. 59/2013-B). All efforts were made to minimize animal suffering and to use the minimal number of animals required to produce reliable results.

Briefly, injured rats acutely administered with TZD (by gavage, dose as indicated in the $x$ axis, figures 4 and 5) at the seventh day after the injury showed a significant increase of the pain threshold (here used as a measure of analgesia) and a reduction of the weight bearing deficit (a condition that reflects aspects of spontaneous pain).

Interestingly, the TZD-induced beneficial effects that emerged in in vivo experiments in injured rats administered with the lowest dose of TZD $(0.3 \mathrm{mg} / \mathrm{kg})$ were paralleled by a significant amelioration of the ex-vivo, in vitro synaptic defects in spinal cord glutamatergic nerve endings (previously described in paragraph 4). In particular, in the TZD-treated injured rats i) the glutamate exocytosis recovered to levels consistent with those observed in sham operated rats; ii) the density of $\mathrm{mGlu} 2 / 3$ receptor proteins increased significantly and iii) the efficiency of the mGlu2/3 autoreceptors was largely restored (70). These data confirm the hypothesis that the antagonism at the serotonergic receptors could re-balance the 


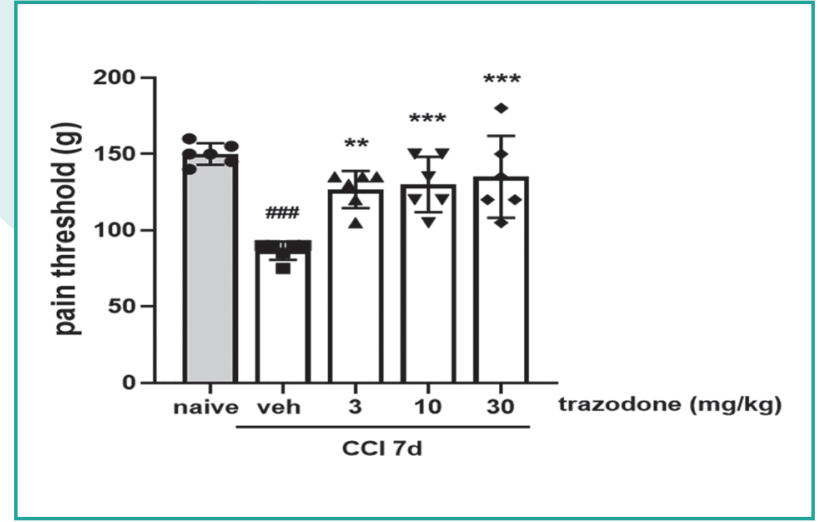

Figure 4. Effect of trazodone oral administration on mechanical hyperalgesia 7 days following rat sciatic nerve ligation. The results are expressed as pain threshold (in grams) recorded $1 \mathrm{~h}$ after treatment administration. \#\#\#P $<0.001$ vs naïve group; ${ }^{* *} \mathrm{P}<$ $0.01,{ }^{* * *} \mathrm{P}<0.001$ vs vehicle $\mathrm{CCl}$ group. $\mathrm{n}=6$ animals/ group.

mGlu2/3-5- $\mathrm{HT}_{2 \mathrm{~A}}$ receptors metamodulation to an almost physiological level, recovering the presynaptic efficiency of the mGlu2/3 autoreceptors and favouring analgesia (70).

To confirm whether the mGlu2/3 receptors could have had a role in the TZD analgesic effect in $\mathrm{CCl}$ rats, in vivo experiments were carried out to verify whether LY341495, which is a potent and systemically active $\mathrm{mGlu} 2 / 3$ receptor antagonist, could prevent the analgesic activity of TZD. To this purpose, TZD $(10 \mathrm{mg} / \mathrm{kg})$ was given at 7 days following surgery, alone or in combination with LY341495 (intraperitoneally given at $1 \mathrm{mg} / \mathrm{kg}, 30$ minutes before TZD). Mechanical hyperalgesia was measured $1 \mathrm{~h}$ post-treatment as the hind paw withdrawal threshold to a noxious mechanical stimulus and was assessed using the paw pressure technique. Thereafter, the reduction in static weight bearing was also measured using an incapacitance tester, a device that measures the weight distributed to each hind paw individually. In these experiments, TZD confirmed its anti-hyperalgesic effect that however was prevented by LY341495 pre-treatment as indicated by the levels of mechanical hyperalgesia (figure 6) and weight bearing deficit (figure 7), definitively proving the main role of

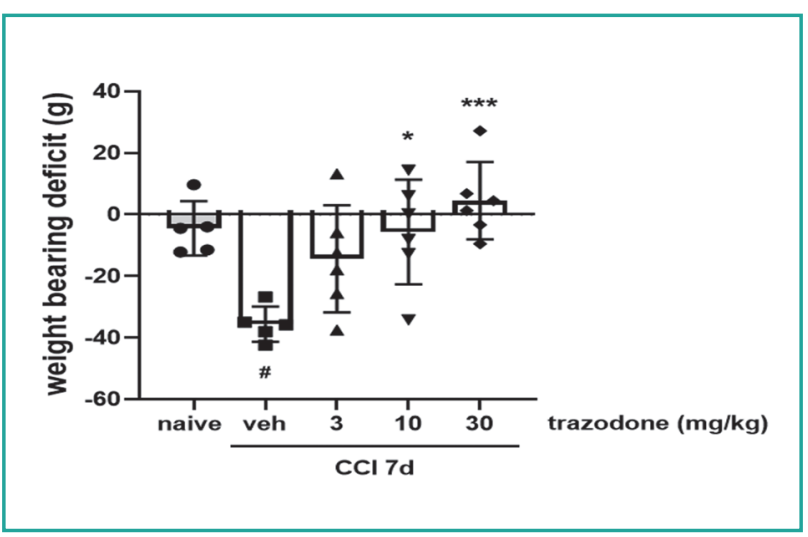

Figure 5. Effect of trazodone oral administration on weight bearing deficit 7 days following rat sciatic nerve ligation. The results are expressed as the difference between the contralateral and ipsilateral paws (in grams) recorded $1 \mathrm{~h}$ after treatment administration. $\# \mathrm{P}<0.05$ vs naïve group; ${ }^{*} \mathrm{P}<0.05$, ${ }^{* *} \mathrm{P}<0.001$ vs vehicle $\mathrm{CCl}$ group. $\mathrm{n}=5-6$ animals/group.

mGlu2/3 receptors in the TZD-induced analgesic activity.

TZD has been already used in human for neuropathic pain. Low-doses of TZD are recommended as an effective treatment option for painful diabetic neuropathy based on data showing that patients receiving this drug experience a complete pain relief with relatively minor side effects $(107,108)$. In addition, in patients with fibromyalgia, TZD did not markedly improve pain intensity, but had a significant effect on pain interference with daily activities $(109,110)$.

Very recently Lipone and colleagues (111) carried out a phase II clinical study to collect data on the efficacy and the safety of low doses of TZD in patients affected by painful diabetic neuropathy. The patients were allocated to groups receiving different doses of TZD alone (30 mg /day or $60 \mathrm{mg} /$ day) together with gabapentin as background therapy. The primary endpoint of the study was to verify changes from baseline by using the Brief Pain Inventory Short Form item 5 after 8 weeks of TZD administration. Secondary endpoints included the responses to other Brief Pain Inventory Short Form items together with the assessment of anxiety, sleep, quality of life, patient's improve- 


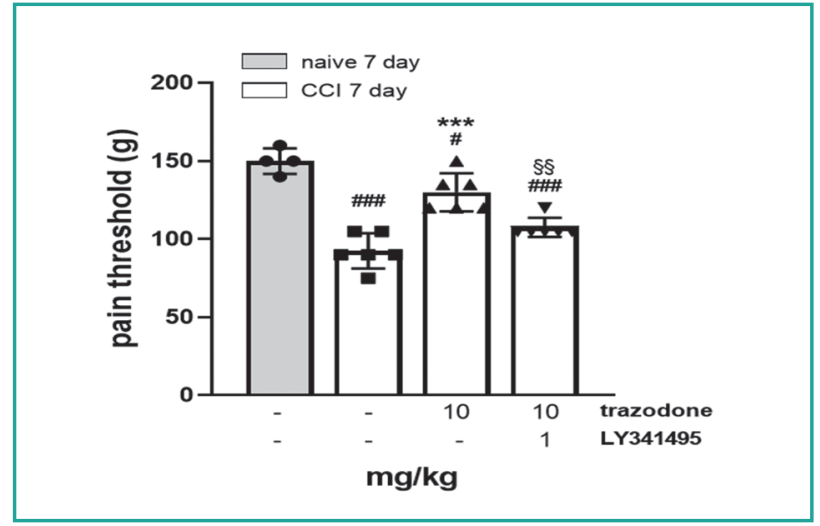

Figure 6. Effect of LY341495 pre-treatment on trazodone oral administration on mechanical hyperalgesia 7 days following rat sciatic nerve ligation. The results are expressed as pain threshold (in grams) recorded $1 \mathrm{~h}$ after treatment administration. \#P $<0.05$, \#\#\#P $<0.001$ vs naïve group; ${ }^{* * *} \mathrm{P}<0.001$ vs vehicle $\mathrm{CCl}$ group; $\S \S \mathrm{P}<0.01$ vs trazodone $\mathrm{CCl}$ group. $n=4-6$ animals/group.

ment, and safety of the treatment. Although the study failed to fulfill the first endpoint, the results unveiled a better performance for the patients receiving the TZD (30 mg/day), with a favorable safety profile, confirming the efficacy of low doses of TZD for treating painful diabetic neuropathy.

\section{CONCLUSIONS}

The concept of metamodulation is innovative because it hugely amplifies the complexity of the synaptic and non-synaptic transmission in the CNS, but also because it paves the road to new unexpected approaches for pharmacological interventions to control the functions of receptors for which safe orthosteric /allosteric ligands are lacking or, if available, cannot be used in therapy due to the concomitant onset of unwanted side effects, tolerance or desensitization that limits their manageability (50).

Metamodulation also poses the basis for the repurposing of drugs for innovative therapeutic approaches as well as for potential clinical conditions that however lack the molecular/ cellular rationale to support their use in clinic. It might be the case of TZD, that was reported to ameliorate, or even relieve, peripheral

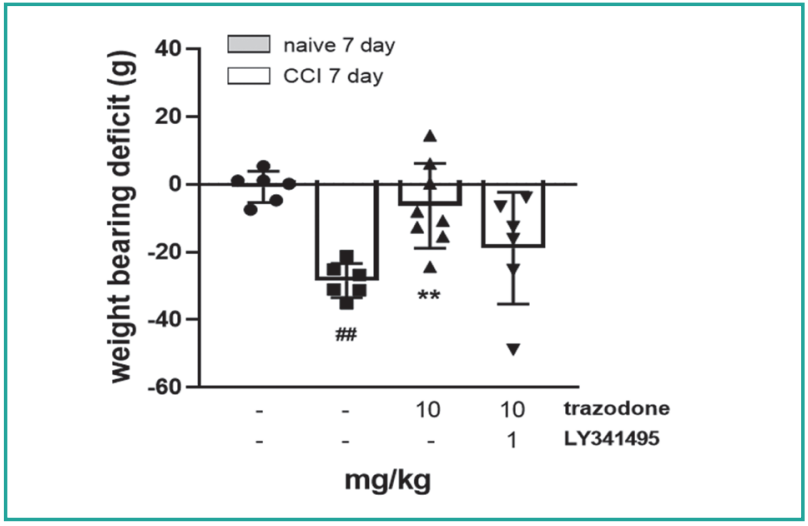

Figure 7. Effect of LY341495 pre-treatment on trazodone oral administration on weight bearing deficit 7 days following rat sciatic nerve ligation. The results are expressed as the difference between the contralateral and ipsilateral paws (in grams) recorded $1 \mathrm{~h}$ after treatment administration. \#\#P $<0.01 \mathrm{vs}$ naïve group; ${ }^{* *} \mathrm{P}<0.01$ vs vehicle $\mathrm{CCl}$ group. $\mathrm{n}=6-8$ animals/group.

neuropathic pain in patients suffering from diabetes 1 and 2, but whose mechanism(s) of action still represents matter of debate. We have here revised preclinical findings that suggest the $5-\mathrm{HT}_{2 \mathrm{~A}}$ receptor-mediated metamodulation of the $\mathrm{mGlu} 2 / 3$ autoreceptors in glutamatergic nerve endings of the spinal cord of mammals as a cellular mechanism underlying the analgesic activity of this drug. By this point of view, TZD might provide a manageable and safe alternative to the use of $\mathrm{mGlu} 2 / 3$ ligands to control the activity of the mGlu2/3 autoreceptors in pathological conditions associated to spinal pain sensitization.

\section{ACKNOWLEDGEMENTS}

We thank Angelini Pharma S.p.A. for supporting this work.

\section{ETHICS}

\section{Fundings}

The study was granted by Angelini Pharma S.p.A. (contract 039(1)PD18114). 


\section{Conflict of interests}

BG, CM, FPDG are employees of Angelini Pharma S.p.A.. GO, AR, GV, AP declare that they have no conflict of interests.

\section{Authors' contribution}

Conceptualization AP; writing AP and BG, reviewing and editing $\mathrm{GO}$,

$A R, C M, G V$, FPDG; Figures: AP, AR, BG; animal experiments: $B G, C M$ and FPDG.

\section{Availability of data and material}

The data presented in this study are available in the article.

\section{Ethical approval}

The experiments were carried out in accordance with the European Communities Council Directive guidelines (Directive 2010/63/EU of 22 September 2010) and approved by the National Council on Animal Care of the Italian Ministry of Health (Authorization n. 59/2013-B).

\section{REFERENCES}

1. Albert U, Lamba P, Stahl SM. Early response to trazodone once-a-day in major depressive disorder: review of the clinical data and putative mechanism for faster onset of action. CNS Spectr 2021;26(3):23242. Doi: $10.1017 /$ S1092852921000304.

2. Fagiolini A, Comandini A, Catena Dell'Osso $\mathrm{M}$, Kasper S. Rediscovering trazodone for the treatment of major depressive disorder. CNS Drugs. 2012;26(12):1033-49. Doi: $10.1007 / s 40263-012-0010-5$. Erratum in: CNS Drugs 2013;27(8):677

3. Fabre LF. Trazodone dosing regimen: experience with single daily administration. J Clin Psychiatry 1990;51 Suppl:23-6.

4. Nierenberg AA, Adler LA, Peselow E, Zornberg G, Rosenthal M. Trazodone for antidepressant-associated insomnia. Am J Psychiatry 1994;151(7):1069-72. Doi: 10.1176/ajp.151.7.1069.

5. Cunningham LA, Borison RL, Carman JS, et al. A comparison of venlafaxine, tra- zodone, and placebo in major depression. J Clin Psychopharmacol 1994;14(4):292.

6. Cuomo A, Ballerini A, Bruni AC, et al. Clinical guidance for the use of trazodone in major depressive disorder and concomitant conditions: pharmacology and clinical practice. Riv Psichiatr 2019;54(4):137-49. Doi: 10.1708/3202.31796.

7. Stahl SM. Mechanism of action of trazodone: a multifunctional drug. CNS Spectr 2009;14(10):536-46. Doi: 10.1017/ s1092852900024020.

8. Owens MJ, Morgan WN, Plott SJ, Nemeroff CB. Neurotransmitter receptor and transporter binding profile of antidepressants and their metabolites. J Pharmacol Exp Ther 1997;283(3):1305-22. PMID: 9400006.

9. Gobert A, Millan MJ. Serotonin (5-HT)2A receptor activation enhances dialysate levels of dopamine and noradrenaline, but not $5-\mathrm{HT}$, in the frontal cortex of freely-moving rats. Neuropharmacology 1999;38(2):3157. Doi: 10.1016/s0028-3908(98)00188-9.

10. Bossini L, Coluccia A, Casolaro I, Benbow J, Amodeo G, De Giorgi R, Fagiolini A. Off-Label Trazodone Prescription: Evidence, Benefits and Risks. Curr Pharm Des 2015;21(23):3343-51. Doi: 10.2174/13816 12821666150619092236.

11. Ghanbari R, El Mansari M, Blier P. Sustained administration of trazodone enhances serotonergic neurotransmission: in vivo electrophysiological study in the rat brain. $J$ Pharmacol Exp Ther. 2010;335(1):197-206. Doi: 10.1124/jpet.110.169417.

12. Wang SJ, Wang KY, Wang WC, Sihra TS. Unexpected inhibitory regulation of glutamate release from rat cerebrocortical nerve terminals by presynaptic 5-hydroxytryptamine-2A receptors. J Neurosci Res 2006;84(7):1528-42. Doi: 10.1002/jnr.21060.

13. Aghajanian GK, Marek GJ. Serotonin induces excitatory postsynaptic potentials in apical dendrites of neocortical pyramidal cells. Neuropharmacology 
1997;36(4-5):589-99. Doi: 10.1016/s00283908(97)00051-8.

14. Pichon X, Wattiez AS, Becamel C, et al. Disrupting 5-HT(2A) receptor/PDZ protein interactions reduces hyperalgesia and enhances SSRI efficacy in neuropathic pain. Mol Ther. 2010 Aug;18(8):1462-70. Doi:10.1038/mt.2010.101.

15. Olivero G, Grilli M, Vergassola $M$, et al. 5-HT2A-mGlu2/3 receptor complex in rat spinal cord glutamatergic nerve endings: a 5-HT2A to mGlu2/3 signalling to amplify presynaptic mechanism of auto-control of glutamate exocytosis. Neuropharmacology 2018;133:429-39.

16. Wang YY, Wei YY, Huang J, Wang W, Tamamaki N, Li YQ, Wu SX. Expression patterns of 5-HT receptor subtypes $1 \mathrm{~A}$ and 2A on GABAergic neurons within the spinal dorsal horn of GAD67-GFP knock-in mice. J Chem Neuroanat 2009;38(1):7581. Doi: 10.1016/j.jchemneu.2009.04.003.

17. Wattiez AS, Dupuis $A$, Privat $A M$, et al. Disruption of $5-\mathrm{HT}_{2 \mathrm{~A}}-\mathrm{PDZ}$ protein interaction differently affects the analgesic efficacy of SSRI, SNRI and TCA in the treatment of traumatic neuropathic pain in rats. Neuropharmacology 2017;125:308-318. Doi: 10.1016/j.neuropharm.2017.07.034.

18. Dupuis A, Wattiez AS, Pinguet J, et al. Increasing spinal $5-\mathrm{HT}_{2 \mathrm{~A}}$ receptor responsiveness mediates anti-allodynic effect and potentiates fluoxetine efficacy in neuropathic rats. Evidence for GABA release. Pharmacol Res 2017;118:93-103. Doi: 10.1016/j.phrs.2016.09.021.

19. Marcoli M, Rosu C, Bonfanti A, Raiteri M, Maura G. Inhibitory presynaptic 5-hydroxytryptamine(2A) receptors regulate evoked glutamate release from rat cerebellar mossy fibers. J Pharmacol Exp Ther 2001;299(3):1106-11.

20. Acton D, Miles GB. Gliotransmission and adenosinergic modulation: insights from mammalian spinal motor networks. J Neurophysiol. 2017;118(6):3311-27. Doi: 10.1152/jn.00230.2017.
21. Olivero G, Vergassola M, Cisani F, Roggeri A, Pittaluga A. Presynaptic Release-regulating Metabotropic Glutamate Receptors: An Update. Curr Neuropharmacol 2020;18(7):655-72. Doi: 10.2174/1570159 X17666191127112339.

22. Pittaluga A, Roggeri A, Vallarino G, Olivero G. Somatostatin, a Presynaptic Modulator of Glutamatergic Signal in the Central Nervous System. Int J Mol Sci 2021;22(11):5864. Doi: 10.3390/ ijms22115864.

23. Marek GJ, Wright RA, Schoepp DD, Monn JA, Aghajanian GK. Physiological antagonism between 5-hydroxytryptamine(2A) and group II metabotropic glutamate receptors in prefrontal cortex. J Pharmacol Exp Ther 2000;292(1):76-87.

24. Marek GJ, Wright RA, Schoepp DD. 5-Hydroxytryptamine2A (5-HT2A) receptor regulation in rat prefrontal cortex: interaction of a phenethylamine hallucinogen and the metabotropic glutamate2/3 receptor agonist LY354740. Neurosci Lett 2006;403(3):256-60. Doi: 10.1016/j. neulet.2006.05.021.

25. González-Maeso J, Ang RL, Yuen T, et al. Identification of a serotonin/glutamate receptor complex implicated in psychosis. Nature 2008;452(7183):93-7. Doi: 10.1038 /nature06612.

26. Molinaro G, Traficante A, Riozzi B, et al. Activation of mGlu2/3 metabotropic glutamate receptors negatively regulates the stimulation of inositol phospholipid hydrolysis mediated by 5-hydroxytryptamine2A serotonin receptors in the frontal cortex of living mice. Mol Pharmacol 2009;76(2):379-87. Doi: 10.1124/ mol.109.056580.

27. Moreno JL, Holloway T, Albizu L, Sealfon SC, González-Maeso J. Metabotropic glutamate $\mathrm{mGlu2}$ receptor is necessary for the pharmacological and behavioral effects induced by hallucinogenic 5-HT2A receptor agonists. Neurosci Lett 2011;493(3):76-9. Doi:10.1016/j.neulet.2011.01.046. 
28. Moreno JL, Muguruza C, Umali A, et al. Identification of three residues essential for 5-hydroxytryptamine 2A-metabotropic glutamate 2 (5-HT2A-mGlu2) receptor heteromerization and its psychoactive behavioral function. J Biol Chem 2012;287(53):44301-19. Doi: 10.1074/jbc. M112.413161.

29. Delille HK, Becker JM, Burkhardt S, et al. Heterocomplex formation of 5-HT2A-mGlu2 and its relevance for cellular signaling cascades. Neuropharmacol 2012;62(7):2184-91. Doi:10.1016/j.neuropharm.2012.01.010.

30. Delille HK, Mezler M, Marek GJ. The two faces of the pharmacological interaction of mGlu2 and 5- $\mathrm{HT}_{2} \mathrm{~A}$ - relevance of receptor heterocomplexes and interaction through functional brain pathways. Neuropharmacol 2013;70:296-305. Doi: 10.1016/j.neuropharm.2013.02.005.

31. Gewirtz JC, Marek GJ. Behavioral evidence for interactions between a hallucinogenic drug and group II metabotropic glutamate receptors. Neuropsychopharmacology 2000;23(5):569-76. Doi: 10.1016/S0893$133 \times(00) 00136-6$.

32. Kłodzinska A, Bijak M, Tokarski K, Pilc A. Group II mGlu receptor agonists inhibit behavioural and electrophysiological effects of DOI in mice. Pharmacol Biochem Behav 2002;73(2):327-32. Doi: 10.1016/ s0091-3057(02)00845-6.

33. Benneyworth MA, Smith RL, Sanders-Bush E. Chronic phenethylamine hallucinogen treatment alters behavioral sensitivity to a metabotropic glutamate $2 / 3$ receptor agonist. Neuropsychopharmacology. 2008 Aug;33(9):2206-16. Doi: 10.1038/ sj.npp. 1301600.

34. Wischhof L, Hollensteiner KJ, Koch $M$. Impulsive behaviour in rats induced by intracortical DOI infusions is antagonized by co-administration of an mGlu2/3 receptor agonist. Behav Pharmacol 2011;22(8):805-13. Doi: 10.1097/ FBP.0b013e32834d6279.
35. Wischhof $L$, Koch M. Pre-treatment with the mGlu2/3 receptor agonist LY379268 attenuates DOl-induced impulsive responding and regional c-Fos protein expression. Psychopharmacology (Berl) 2012;219(2):387400. Doi: 10.1007/s00213-011-2441-y.

36. Wischhof L, Koch M. 5-HT2A and mGlu2/3 receptor interactions: on their relevance to cognitive function and psychosis. Behav Pharmacol 2016;27(1):1-11. Doi: 10.1097/ FBP.0000000000000183.

37. Marek GJ, Aghajanian GK. 5-HT2A receptor or alpha1-adrenoceptor activation induces excitatory postsynaptic currents in layer $\mathrm{V}$ pyramidal cells of the medial prefrontal cortex. Eur J Pharmacol 1999;367(2-3):197-206. Doi: 10.1016/ s0014-2999(98)00945-5.

38. Gewirtz JC, Chen AC, Terwilliger R, Duman RC, Marek GJ. Modulation of DOl-induced increases in cortical BDNF expression by group II mGlu receptors. Pharmacol Biochem Behav 2002;73(2):317-26. Doi: 10.1016/s0091-3057(02)00844-4.

39. Zhai Y, George CA, Zhai J, Nisenbaum ES, Johnson MP, Nisenbaum LK. Group II metabotropic glutamate receptor modulation of DOl-induced c-fos mRNA and excitatory responses in the cerebral cortex. Neuropsychopharmacology 2003;28(1):45-52. Doi: 10.1038/sj.npp.1300013.

40. Fribourg M, Moreno JL, Holloway $T$, et al. Decoding the signaling of a GPCR heteromeric complex reveals a unifying mechanism of action of antipsychotic drugs. Cell 2011;147(5):1011-23. Doi: 10.1016/j. cell.2011.09.055.

41. Murat S, Bigot $M$, Chapron J, et al. 5-HT2A receptor-dependent phosphorylation of mGlu2 receptor at Serine 843 promotes mGlu2 receptor-operated Gi/o signaling. Mol Psychiatry 2019;24(11):1610-26. Doi: 10.1038/s41380-018-0069-6.

42. Ferré S, Quiroz C, Woods AS, et al. An update on adenosine A2A-dopamine D2 receptor interactions: implications for the function of $G$ protein-coupled receptors. 
Curr Pharm Des 2008;14(15):1468-74. Doi: $10.2174 / 138161208784480108$.

43. Borroto-Escuela DO, Romero-Fernandez W, Tarakanov AO, Ciruela F, Agnati LF, Fuxe $K$. On the existence of a possible A2A-D2$\beta$-Arrestin2 complex: A2A agonist modulation of D2 agonist-induced $\beta$-arrestin2 recruitment. J Mol Biol 2011;406(5):687-99. Doi: 10.1016/j.jmb.2011.01.022.

44. Pittaluga A, Bonfanti A, Raiteri M. Somatostatin potentiates NMDA receptor function via activation of $\operatorname{Ins} \mathrm{P}(3)$ receptors and PKC leading to removal of the $\mathrm{Mg}(2+)$ block without depolarization. $\mathrm{Br} \mathrm{J}$ Pharmacol 2000;130(3):557-66. Doi: 10.1038/ sj.bjp.0703346.

45. Marchi M, Grilli M, Pittaluga AM. Nicotinic modulation of glutamate receptor function at nerve terminal level: a fine-tuning of synaptic signals. Front Pharmacol 2015;6:89. Doi: 10.3389/fphar.2015.00089.

46. Fuxe K, Agnati LF, Benfenati F. Evidence for the existence of receptor--receptor interactions in the central nervous system. Studies on the regulation of monoamine receptors by neuropeptides. J Neural Transm Suppl 1983;18:165-79.

47. Fuxe K, Agnati LF, Borroto-Escuela DO. The impact of receptor-receptor interactions in heteroreceptor complexes on brain plasticity. Expert Rev Neurother 2014;14(7):719-21. Doi: 10.1586/14737175.2014.922878.

48. Borroto-Escuela DO, Romero-Fernandez W, Narvaez M, Oflijan J, Agnati LF, Fuxe K. Hallucinogenic 5-HT2AR agonists LSD and $\mathrm{DOI}$ enhance dopamine D2R protomer recognition and signaling of D2-5-HT2A heteroreceptor complexes. Biochem Biophys Res Commun 2014;443(1):278-84. Doi: 10.1016/j.bbrc.2013.11.104.

49. Zoli M, Agnati LF, Hedlund PB, Li XM, Ferré S, Fuxe K. Receptor-receptor interactions as an integrative mechanism in nerve cells. Mol Neurobiol 1993 Fall-Winter;7(3-4):293-334. Doi: 10.1007/ BF02769180.
50. Agnati LF, Tarakanov AO, Ferré S, Fuxe K, Guidolin D. Receptor-receptor interactions, receptor mosaics, and basic principles of molecular network organization: possible implications for drug development. J Mol Neurosci 2005;26(2-3):193208. Doi: 10.1385/JMN:26:2-3:193.

51. Ribeiro JA, Sebastião AM. Modulation and metamodulation of synapses by adenosine. Acta Physiol (Oxf) 2010;199(2):161-9. Doi: 10.1111/j.1748-1716.2010.02115.x.

52. Schoepp DD, Marek GJ. Preclinical pharmacology of mGlu2/3 receptor agonists: novel agents for schizophrenia? Curr Drug Targets CNS Neurol Disord 2002;1(2):21525. Doi: $10.2174 / 1568007024606177$.

53. Matrisciano F, Panaccione I, Grayson DR, Nicoletti F, Guidotti A. Metabotropic Glutamate 2/3 Receptors and Epigenetic Modifications in Psychotic Disorders: A Review. Curr Neuropharmacol. 2016;14(1):41-7. Doi: 10.2174/1570159x13666150713174242.

54. Matrisciano F, Dong E, Nicoletti F, Guidotti A. Epigenetic Alterations in Prenatal Stress Mice as an Endophenotype Model for Schizophrenia: Role of Metabotropic Glutamate 2/3 Receptors. Front Mol Neurosci 2018;11:423. Doi: 10.3389/fnmol.2018.00423.

55. Ellaithy A, Younkin J, González-Maeso J, Logothetis DE. Positive allosteric modulators of metabotropic glutamate 2 receptors in schizophrenia treatment. Trends Neurosci 2015;38(8):506-16. Doi: 10.1016/j. tins.2015.06.002.

56. Cartmell J, Schoepp DD. Regulation of neurotransmitter release by metabotropic glutamate receptors. J Neurochem 2000;75(3):889-907. Doi: 10.1046/j.14714159.2000.0750889.x.

57. Niswender CM, Conn PJ. Metabotropic glutamate receptors: physiology, pharmacology, and disease. Annu Rev Pharmacol Toxicol 2010;50:295-322. Doi: 10.1146/annurev.pharmtox.011008.145533.

58. Nicoletti F, Bockaert J, Collingridge GL, et al. Metabotropic glutamate receptors: 
from the workbench to the bedside. Neuropharmacology 2011;60(7-8):1017-41. Doi: 10.1016/j.neuropharm.2010.10.022.

59. Di Prisco S, Merega E, Bonfiglio T, et al. Presynaptic, release-regulating mGlu2 -preferring and mGlu3 -preferring autoreceptors in CNS: pharmacological profiles and functional roles in demyelinating disease. Br J Pharmacol 2016;173(9):1465-77. Doi: 10.1111/bph.13442.

60. Raiteri M, Angelini F, Levi G. A simple apparatus for studying the release of neurotransmitters from synaptosomes. Eur J Pharmacol 1974;25(3):411-4. Doi: 10.1016/0014-2999(74)90272-6.

61. Pittaluga A. Presynaptic Release-Regulating mGlu1 Receptors in Central Nervous System. Front Pharmacol 2016;7:295. Doi: 10.3389/fphar.2016.00295.

62. Pittaluga A. Acute Functional Adaptations in Isolated Presynaptic Terminals Unveil Synaptosomal Learning and Memory. Int J Mol 2019;Sci 20(15). Doi: 10.3390/ ijms20153641.

63. Ferré S, Ciruela F, Casadó V, Pardo L. Oligomerization of $G$ protein-coupled receptors: Still doubted? Prog Mol Biol Transl Sci 2020;169:297-321. Doi: 10.1016/ bs.pmbts.2019.11.006.

64. Holloway T, Moreno JL, Umali A, et al. Prenatal stress induces schizophrenia-like alterations of serotonin $2 \mathrm{~A}$ and metabotropic glutamate 2 receptors in the adult offspring: role of maternal immune system. J Neurosci 2013;33(3):1088-98. Doi: 10.1523/JNEUROSCI.2331-12.2013.

65. Mocci G, Jiménez-Sánchez L, Adell A, Cortés R, Artigas F. Expression of 5-HT2A receptors in prefrontal cortex pyramidal neurons projecting to nucleus accumbens. Potential relevance for atypical antipsychotic action. Neuropharmacology 2014;79:49-58. Doi: 10.1016/j.neuropharm.2013.10.021.

66. Walker AG, Conn PJ. Group I and group II metabotropic glutamate receptor allosteric modulators as novel potential antipsychot- ics. Curr Opin Pharmacol 2015;20:40-5. Doi: 10.1016/j.coph.2014.11.003.

67. Nicoletti F, Orlando R, Di Menna L, et al. Targeting mGlu Receptors for Optimization of Antipsychotic Activity and Disease-Modifying Effect in Schizophrenia. Front Psychiatry 2019;10:49. Doi: 10.3389/ fpsyt.2019.00049.

68. Li ML, Hu XQ, Li F, Gao WJ. Perspectives on the mGluR2/3 agonists as a therapeutic target for schizophrenia: Still promising or a dead end? Prog Neuropsychopharmacol Biol Psychiatry 2015;60:66-76. Doi: 10.1016/j.pnpbp.2015.02.012.

69. Trabanco AA, Bartolomé JM, Cid JM. mGluR2 positive allosteric modulators: an updated patent review (2013-2018). Expert Opin Ther Pat 2019;29(7):497-507. Doi: 10.1080/13543776.2019.1637421.

70. Cisani F, Roggeri A, Olivero G, et al. Acute Low Dose of Trazodone Recovers Glutamate Release Efficiency and mGlu2/3 Autoreceptor Impairments in the Spinal Cord of Rats Suffering From Chronic Sciatic Ligation. Front Pharmacol 2020;11:1108. Doi: 10.3389/fphar.2020.01108.

71. Somers DL, Clemente FR. Contralateral high or a combination of high- and low-frequency transcutaneous electrical nerve stimulation reduces mechanical allodynia and alters dorsal horn neurotransmitter content in neuropathic rats. J Pain 2009;10(2):221-9. Doi: 10.1016/j. jpain.2008.08.008.

72. Wang ZT, Yu G, Wang HS, Yi SP, Su RB, Gong ZH. Changes in VGLUT2 expression and function in pain-related supraspinal regions correlate with the pathogenesis of neuropathic pain in a mouse spared nerve injury model. Brain Res 2015;1624:515524. Doi: 10.1016/j.brainres.2015.08.010.

73. Morioka N, Zhang FF, Nakamura Y, Kitamura T, Hisaoka-Nakashima K, Nakata Y. Tumor necrosis factor-mediated downregulation of spinal astrocytic connexin 43 leads to increased glutamatergic neurotransmission and neuropathic pain in mice. 
Brain Behav Immun 2015;49:293-310. Doi: 10.1016/j.bbi.2015.06.015.

74. Danbolt NC. Glutamate uptake. Prog Neurobiol. 2001 Sep;65(1):1-105. Doi: 1016/ s0301-0082(00)00067-8.

75. Napier IA, Mohammadi SA, Christie MJ. Glutamate transporter dysfunction associated with nerve injury-induced pain in mice. J Neurophysiol 2012;107(2):649-57. Doi: 10.1152/jn.00763.2011.

76. Liaw WJ, Stephens RL Jr, Binns BC, et al. Spinal glutamate uptake is critical for maintaining normal sensory transmission in rat spinal cord. Pain 2005;115(1-2):6070. Doi: 10.1016/j.pain.2005.02.006.

77. Weng HR, Chen JH, Cata JP. Inhibition of glutamate uptake in the spinal cord induces hyperalgesia and increased responses of spinal dorsal horn neurons to peripheral afferent stimulation. Neuroscience. 2006;138(4):1351-60. Doi: 10.1016/j.neuroscience.2005.11.061.

78. Sung B, Lim G, Mao J. Altered expression and uptake activity of spinal glutamate transporters after nerve injury contribute to the pathogenesis of neuropathic pain in rats. J Neurosci 2003 Apr 1;23(7):2899-910. Doi: 10.1523/JNEUROSCI.23-07-02899.2003.

79. Sung B, Wang S, Zhou B, et al. Altered spinal arachidonic acid turnover after peripheral nerve injury regulates regional glutamate concentration and neuropathic pain behaviors in rats. Pain 2007;131(1-2):12131. Doi: 10.1016/j.pain.2006.12.020.

80. Xin WJ, Weng HR, Dougherty PM. Plasticity in expression of the glutamate transporters GLT-1 and GLAST in spinal dorsal horn glial cells following partial sciatic nerve ligation. Mol Pain 2009 Mar 26;5:15. Doi: 10.1186/1744-8069-5-15.

81. Fariello RG, Ghelardini C, Di Cesare Mannelli $L$, et al. Broad spectrum and prolonged efficacy of dimiracetam in models of neuropathic pain. Neuropharmacology 2014;81:85-94. Doi: 10.1016/j.neuropharm.2014.01.029.
82. Dickenson AH, Chapman V, Green GM. The pharmacology of excitatory and inhibitory amino acid-mediated events in the transmission and modulation of pain in the spinal cord. Gen Pharmacol 1997;28(5):6338. Doi: 10.1016/s0306-3623(96)00359-x.

83. Mills CD, Fullwood SD, Hulsebosch CE. Changes in metabotropic glutamate receptor expression following spinal cord injury. Exp Neurol 2001;170(2):244-57. Doi: 10.1006/exnr.2001.7721.

84. Mills CD, Johnson KM, Hulsebosch CE. Role of group II and group III metabotropic glutamate receptors in spinal cord injury. Exp Neurol 2002;173(1):153-67. Doi: 10.1006/exnr.2001.7828.

85. Osikowicz M, Skup M, Mika J, Makuch W, Czarkowska-Bauch J, Przewlocka B. Glial inhibitors influence the mRNA and protein levels of mGlu2/3, 5 and 7 receptors and potentiate the analgesic effects of their ligands in a mouse model of neuropathic pain. Pain 2009;147(1-3):175-86. Doi: 10.1016/j.pain.2009.09.002.

86. Neale JH, Olszewski RT, Gehl LM, Wroblewska B, Bzdega T. The neurotransmitter $\mathrm{N}$-acetylaspartylglutamate in models of pain, ALS, diabetic neuropathy, CNS injury and schizophrenia. Trends Pharmacol Sci 2005;26(9):477-84. Doi: 10.1016/j. tips.2005.07.004.

87. Chiechio S, Copani A, Zammataro M, Battaglia G, Gereau RW $4^{\text {th }}$, Nicoletti F. Transcriptional regulation of type-2 metabotropic glutamate receptors: an epigenetic path to novel treatments for chronic pain. Trends Pharmacol Sci 2010;31(4):153-60. Doi: 10.1016/j.tips.2009.12.003.

88. Chiechio S. Modulation of Chronic Pain by Metabotropic Glutamate Receptors. Adv Pharmacol 2016;75:63-89. Doi: 10.1016/ bs.apha.2015.11.001.

89. Chiechio S, Nicoletti F. Metabotropic glutamate receptors and the control of chronic pain. Curr Opin Pharmacol 2012;12(1):2834. Doi: 10.1016/j.coph.2011.10.010. 
90. Neale JH, Yamamoto T. N-acetylaspartylglutamate (NAAG) and glutamate carboxypeptidase II: An abundant peptide neurotransmitter-enzyme system with multiple clinical applications. Prog Neurobiol 2020;184:101722. Doi: 10.1016/j.pneurobio.2019.101722.

91. Bernabucci M, Notartomaso S, Zappulla $C$, et al. N-Acetyl-cysteine causes analgesia by reinforcing the endogenous activation of type-2 metabotropic glutamate receptors. Mol Pain 2012;8:77. Doi: 10.1186/1744-8069-8-77.

92. Truini A, Piroso S, Pasquale E, et al. N-acetyl-cysteine, a drug that enhances the endogenous activation of group-II metabotropic glutamate receptors, inhibits nociceptive transmission in humans. Mol Pain 2015;11:14. Doi: 10.1186/s12990015-0009-2.

93. Zhao ZQ, Chiechio S, Sun YG, et al. Mice lacking central serotonergic neurons show enhanced inflammatory pain and an impaired analgesic response to antidepressant drugs. J Neurosci 2007;30;27(22):6045-53. Doi: 10.1523/ JNEUROSCI.1623-07.2007.

94. Perrin FE, Noristani HN. Serotonergic mechanisms in spinal cord injury. Exp Neurol 2019;318:174-91. Doi: 10.1016/j. expneurol.2019.05.007.

95. Liu QQ, Yao XX, Gao SH, et al. Role of 5-HT receptors in neuropathic pain: potential therapeutic implications. Pharmacol Res. 2020 Sep;159:104949. Doi: 10.1016/j. phrs.2020.104949.

96. Okamoto K, Imbe H, Kimura A, Donishi T, Tamai Y, Senba E. Activation of central 5-HT2A receptors reduces the craniofacial nociception of rats. Neuroscience 2007;147(4):1090-102. Doi: 10.1016/j.neuroscience.2007.05.012.

97. Lopez-Alvarez VM, Puigdomenech $M$, Navarro X, Cobianchi S. Monoaminergic descending pathways contribute to modulation of neuropathic pain by increasing-intensity treadmill exercise af- ter peripheral nerve injury. Exp Neurol 2018;299(Pt A):42-55. Doi: 10.1016/j.expneurol.2017.10.007.

98. Aira Z, Buesa I, Gallego M, et al. Time-dependent cross talk between spinal serotonin 5 -HT2A receptor and mGluR1 subserves spinal hyperexcitability and neuropathic pain after nerve injury. J Neurosci 2012;32(39):13568-81. Doi: 10.1523/JNEUROSCI.1364-12.2012.

99. Wang D, Chen T, Gao Y, Quirion R, Hong Y. Inhibition of SNL-induced upregulation of CGRP and NPY in the spinal cord and dorsal root ganglia by the 5-HT(2A) receptor antagonist ketanserin in rats. Pharmacol Biochem Behav 2012;101(3):379-86. Doi: 10.1016/j. pbb.2012.02.004.

100. Belinskaia DA, Belinskaia MA, Barygin OI, Vanchakova NP, Shestakova NN. Psychotropic Drugs for the Management of Chronic Pain and Itch. Pharmaceuticals (Basel) 2019;12(2):99. Doi: 10.3390/ ph12020099.

101. Schreiber S, Backer MM, Herman I, Shamir D, Boniel T, Pick CG. The antinociceptive effect of trazodone in mice is mediated through both mu-opioid and serotonergic mechanisms. Behav Brain Res 2000;114(1-2):51-6. Doi: 10.1016/ s0166-4328(00)00185-6.

102. Garrone B, di Matteo A, Amato A. Synergistic interaction between trazodone and gabapentin in rodent models of neuropathic pain. PLoS One 2021;16(1):e0244649. Doi: 10.1371/journal.pone.0244649.

103. Zhang R, Nagata $T$, Hayashi T, Miyata M, Kawakami Y. Intracerebroventricular injection of trazodone produces 5-HT receptor subtype mediated anti-nociception at the supraspinal and spinal levels. Eur Neuropsychopharmacol 2004;14(5):419-24. Doi: 10.1016/j.euroneuro.2003.12.006.

104. Bennett GJ, Xie YK. A peripheral mononeuropathy in rat that produces disorders of pain sensation like those seen 
in man. Pain 1988;33(1):87-107. Doi: 10.1016/0304-3959(88)90209-6.

105. Le Cudennec C, Castagné V. Face-toface comparison of the predictive validity of two models of neuropathic pain in the rat: analgesic activity of pregabalin, tramadol and duloxetine. Eur J Pharmacol 2014;735:17-25. Doi: 10.1016/j.ejphar.2014.04.003.

106. Okuda K, Takanishi T, Yoshimoto K, Ueda S. Trazodone hydrochloride attenuates thermal hyperalgesia in a chronic constriction injury rat model. Eur J Anaesthesiol 2003;20(5):409-15. Doi: 10.1017/ s0265021503000632.

107. Khurana RC. Treatment of painful diabetic neuropathy with trazodone. JAMA 1983 Sep 16;250(11):1392. Doi: 10.1001/ jama.1983.03340110016015.

108. Wilson RC. The use of low-dose trazodone in the treatment of painful diabetic neuropathy. J Am Podiatr Med Assoc 1999;89(9):468-71. Doi: 10.7547/87507315-89-9-468.
109. Morillas-Arques P, Rodriguez-Lopez CM, Molina-Barea R, Rico-Villademoros F, Calandre EP. Trazodone for the treatment of fibromyalgia: an open-label, 12-week study. BMC Musculoskelet Disord 2010;11:204. Doi: 10.1186/14712474-11-204.

110. Calandre EP, Morillas-Arques $P$, Molina-Barea R, Rodriguez-Lopez CM, Rico-Villademoros F. Trazodone plus pregabalin combination in the treatment of fibromyalgia: a two-phase, 24-week, open-label uncontrolled study. BMC Musculoskelet Disord 2011;12:95. Doi: 10.1186/1471-2474-12-95.

111. Lipone $P$, Ehler $E$, Nastaj $M$, et al. Efficacy and Safety of Low Doses of Trazodone in Patients Affected by Painful Diabetic Neuropathy and Treated with Gabapentin: A Randomized Controlled Pilot Study. CNS Drugs 2020;34(11):1177-89. Doi: $10.1007 / \mathrm{s} 40263-020-00760-2$. 